\title{
Impact of health legislation on the sale of anorectics in a city in the Amazon region
}

\author{
Luana Valéria da Silva CASTRO ${ }^{1}$, Gilvo FARIAS JUNIOR ${ }^{1}$, Francisco Martins TEIXEIRA², José Ricardo dos \\ Santos VIEIRA ${ }^{3}$, Cristiane do Socorro Ferraz MAIA ${ }^{2,4}$
}

\begin{abstract}
Objectives: The International Narcotics Control Board released its 2005 annual report, highlighting the Brazil population as one of the largest consumers of anorectics. In Brazil, the National Health Surveillance Agency issued the resolution RDC 58/2007 in order to control the prescription and sale of such drugs. In Belém, the biggest city in the Brazilian Amazon region, this resolution came into force in 2008, leading to inspections of drugstores and magistral pharmacies. The aim of this work was to evaluate the consumption of psychotropic anorectic drugs and the impact of RDC 58/2007 on the prescription and dispensing of anorectics in drugstores and magistral pharmacies in Belém. Methodology: A retrospective quantitative and descriptive study was conducted of records from the Municipal Department of Health Surveillance of Belém, for 2005 to 2008. The differences in findings were regarded significant when $\mathrm{p}<0.05$. Results: A total of 1,641 balance sheets of drugstores and magistral pharmacies were analyzed. Amfepramone was the most dispensed medication, followed by fenproporex and mazindol. The highest consumption of anorectics occurred in magistral pharmacies. In 2008, there was a significant reduction in dispensing of anorectics, in drugstores as well as in magistral pharmacies. Conclusions: This study showed that there was a decrease in the dispensing of anorectics after RDC 58/2007 came into force, and that the magistral pharmacies dispensed more of these drugs. This resolution is a remarkable tool in health control, where it is of great benefit to public health and contributes substantially to the rational use of medicines in Brazil.
\end{abstract}

KEYWORDS: Anorectic drugs. Amfepramone. Fenproporex. Mazindol. Health surveillance.

\section{Impacto da legislação sanitária na comercialização de anorexígenos em uma cidade da Amazônia}

\begin{abstract}
RESUMO
Objetivos: O International Narcotics Control Board publicou em 2005 sua pesquisa anual que demonstrou que a população brasileira são um dos maiores consumidores de anorexígenos. No Brasil, a Agência Nacional de Vigilância Sanitária publicou a resolução RDC 58/2007 com o objetivo de controlar a prescrição e comercialização deste tipo de medicamento. Em Belém, a maior cidade da Amazônia brasileira, esta resolução entrou em vigor em 2008, levando à inspeçōes em drogarias e farmácias. Este trabalho propóe avaliar o consumo de psicotrópicos anorexígenos e o impacto da RDC 58/2007 na prescrição e dispensação de anorexígenos nas drogarias e farmácias magistrais de Belém. Metodologia: foi realizado um estudo retrospectivo, quantitativo e descritivo, com dados coletados do Departamento de Vigilância Sanitária de Belém, de 2005 a 2008. Os dados foram considerados quando $\mathrm{p}<0,05$. Resultados: Um total de 1.641 balanços foram analisados oriundos de drogarias e farmácias magistrais. Anfepramona foi o medicamento mais dispensado, seguido do femproporex e manzidol. O maior consumo de anorexígenos ocorreu nas farmácias magistrais. Em 2008, houve uma redução significativa na dispensação de anorexígenos, tanto em drogarias quanto em farmácias magistrais. Conclusôes: Este estudo demonstrou que houve uma diminuição na dispensação de anorexígenos após a entrada em vigor da RDC 58/2007, e as farmácias magistrais foram responsáveis por um elevado número na dispensação destes medicamentos. Esta resolução é um marco divisor no controle sanitário, para enorme benefício da saúde pública, contribuindo substancialmente para o uso racional de medicamentos no Brasil.
\end{abstract}

KEYWORDS: Anorexígenos. Anfepramona. Femproporex. Mazindol. Vigilância Sanitária.

\footnotetext{
1 Instituto Brasileiro de Pós-Graduação e Extensão. Curitiba, PR, Brasil.

2 Universidade Federal do Pará. Instituto de Ciências da Saúde. Faculdade de Farmácia. Belém, PA, Brasil.

${ }^{3}$ Universidade Federal do Pará. Instituto de Ciências Biológicas. Belém, PA, Brasil.

${ }^{4}$ Corresponding author: Faculdade de Farmácia. Universidade Federal do Pará - UFPA. Rua Augusto Côrrea, nº 01 . Campus Universitário - Guamá CEP: 66.075-900, Belém, PA, Brasil. Telefone: (91) 32017202. E-mail: crismaia@ufpa.br
} 
Impact of health legislation on the sale of anorectics in a city in the Amazon region

\section{INTRODUCTION}

In many countries, the prevalence of obesity or overweight has risen dramatically. The World Health Organization (WHO), in its 1997 report, warned about a global epidemic of obesity (Arrais et al. 1997; WHO 1997; Philipson 2001) and the need for primary prevention of overweight (Sartorelli and Granco 2003).

According to Jeffreys et al. (2003), the treatment of obesity is complex and multidisciplinary, and there are many treatment options for obesity and overweight. The therapeutic choice depends on the severity and the associated complications in the patient (ABESO 2009).

The treatment includes non-pharmacological, pharmacological and surgical procedures, where those most indicated are the non-pharmacological procedures, such as caloric restriction, moderate and daily exercise, and monitoring for at least for three months (Salzano and Cordás 2004; Wannmacher 2004).

When the non-pharmacological treatment is not effective, or the patient has a body mass index (BMI) higher than 30, or there are diseases associated with obesity, pharmacological procedures may be adopted (Wannmacher 2004). For this, the drugs most used in the pharmacological treatment of the obesity are the anorectic agents, especially pancreatic lipase inhibitors and serotonin and norepinephrine reuptake inhibitors (Wannmacher 2004).

Currently, Brazil has five registered drugs for obesity treatment: diethylpropion (amfepramone), fenproporex, mazindol, sibutramine and orlistat (ABESO 2009). Psychotropic drugs, such as fenproporex, amfepramone, and mazindol, are drugs that cause anorexia, that is, reduction or loss of appetite, and as mentioned above, they are indicated as an adjuvant in obesity treatment and are not recommended in primary treatment for promoting weight loss (Allison et al. 2001; Campbell 2003, Wadden et al. 2005).

Appetite suppressants are medicines that suppress appetite and hunger feelings. Schedule IV of the Convention on Psychotropic Substances of 1971 lists 14 of these medicines, of which the most produced and consumed around the world in the 2004 were phentermine (45\%), fenproporex (23\%), amfepramone (18\%), and mazindol (9\%) (International Narcotics Control Board 2005). These drugs must be prescribed by a doctor and have been studied in great detail with regard to risks and benefits to the patient (JIFE 2007). Data from WHO showed that the consumption of anorectics in Brazil has increased by $500 \%$, an important fact that should not to be ignored (Carneiro et al. 2008).

In Brazil, one of the health laws that control anorectics is Ordinance 344/98, which determines standards about the marketing and prescription of controlled drugs. The substances are rolled, according to its pharmacological characteristics. The anorectics are included in a B2 roll. This ordinance also obliges drugstores and pharmacies to inform the health surveillance agency about the dispensing of controlled drugs.

In 2007, ANVISA published a regulation called RDC $58 / 2007$, which is aimed at improving the control and inspection of the use of anorectic substances, where the control of these drugs is increased, and they are named in the B2 roll, Ordinance 344. This resolution introduced a new prescription, called prescription notification B2. Besides, RDC 58/2007 determines the defined daily dose of anorectics (fenproporex, amfepramone and mazindol).

Fenproporex was subjected to international inspection in 1986, and since then only Brazil, France, Switzerland and, more recently, Germany and India, have announced its manufacture. After a marked increase of $3 \mathrm{t}$ in 1998 to $10 \mathrm{t}$ in 2003, the total reported production of fenproporex decreased to $5 \mathrm{t}$ in 2004 (Wannmacher 2004). Worldwide production of this drug has increased by $82 \%$ in 2005, reaching $9.5 \mathrm{t}$ and again reduced to $7.3 \mathrm{t}$ in 2006. Brazil, Belgium, and India were the only manufacturers of the substance this year, when Brazil produced $77 \%$ of the total (Carneiro 2008).

In 2006, total amfepramone production grew to about $23 \mathrm{t}$ Three countries reported manufacturing amfepramone in that year: Brazil (13.7 t), Switzerland (8.1 t) and Italy $(738 \mathrm{~kg})$. The volume of production in Brazil has decreased considerably since 2005, when 27.6 t of amfepramone were manufactured. Brazil, for a long time, was the main consumer country (3 DDD per 1,000 inhabitants per day). In 2006, the consumption of amfepramone in Brazil accounted for $89 \%$ of world consumption. Major imports of amfepramone in 2006 were reported by Brazil (4.2 t), Mexico (815 kg), and Germany (401 kg) (Carneiro 2008).

Mazindol is almost exclusively manufactured in Brazil: an average of $34 \mathrm{~kg}$ from 2002 to 2006, nearly half of it was destined for domestic consumption while the rest was exported. The worldwide use of mazindol fell sharply from $702 \mathrm{~kg}$ in 1998 to an annual average of $173 \mathrm{~kg}$ from 2002 to 2006 (Carneiro 2008).

Authors have described that in 1999 of the 108,215 prescriptions of drugs controlled by ordinance 344/98, 26,930 were anorectics, confirming abuse of that class of drug in the treatment of obesity, with ten times more prescriptions for diethylpropion and fenproporex for women than men. The few existing magistral pharmacies dispensed more prescriptions than did drugstores (Noto et al. 2002). Total global consumption of anorectic drugs practically takes place in Brazil, according to research carried out by the International Narcotics Control Board in 2005 (International Narcotics Control Board 2005). 
This work evaluated the consumption of appetite suppressants in Belém, the capital of Para State in Brazil and the largest city in Amazon region, from 2005 to 2008 and the impact of the issue of the resolution of Brazilian National Surveillance Agency (ANVISA) RDC 58 of September 5, 2007, by quantifying the prescription and dispensing of anorectic drugs sold by drugstores and magistral pharmacies from 2005 to 2008. RDC ANVISA number 58 of September 5, 2007 (Brasil 2007), which came into force in January 2008 was set as a delimiter mark for this time interval.

\section{MATERIALS AND METHODS}

A retrospective descriptive quantitative study was conducted about the prescription and dispensing of appetite suppressants in the city of Belém on the basis of data collected from the records of the Municipal Department of Health Surveillance. RDC 58 of September 5, 2007 was used as a timeframe enclosing the years to be analyzed. Thus, two study periods were established to be evaluated, prior to (2005 to 2007) and after (2008) the implementation of that resolution. After approval by the Ethics Committee, an authorization was given by the director of Health Surveillance to perform data collection.

Dispensing records were analyzed through the so-called balance sheet of psychoactive drugs and other medicines subject to special control (in Portuguese $\mathrm{BMPO} / \mathrm{BSPO}$ ) sent by drugstores and magistral pharmacies, as required (Brasil 1998). This document is usually submitted every three months to the Municipal Division of Health Surveillance of Drugs and Medicines (in Portuguese DVSDM), and may include all drugs dispensed by the drugstore or pharmacy in that period and later checked by the pharmacist of the Health Surveillance. The checked copy is given back to the technical manager of drugstore or magistral pharmacy, and another copy is filed with DVSDM.

This work included all data on dispensing by drugstores issued in the dispensing registries (BMPO/BSPO), and data discriminated the manufacturer of psychotropic substances dispensed by magistral pharmacies from January 2005 to December 2008. All information that did not meet the requirements described above was excluded as well as data from drugstores connected to a hospital network and data from establishments that had no formation on sales of such anorectic drugs.

Data analysis was carried out using electronic tabs in Excel Microsoft version 2007, GraphPad Prism 5 and Biostat 5. The data were tabulate and express in tables and graphs in percentage and DDD/1,000 inhabitants per year. Significance of differences between data was determined by the chi-square test for the proportion of drugs consumed over the years and the difference in sales between drugstores and pharmacies. Differences were regarded significant when $\mathrm{p}<0.05$.

DDD is part of the Anatomical Therapeutic Chemical/ Defined Daily Doses system (ATC/DDD) (WHO 2011). DDD is recommended by the World Health Organization (WHO) and serves as the tool to define the amount of drugs consumed, and its use generates information that permits the comparison of use. DDD is the median daily dose for its principal indication. This technical measurement unit allows the comparison of periods of time and use of the medications in the different places (Perini and Acurcio 2000).

The formula applied to the DDD calculation was:

$\mathrm{DDD} / 1,000$ inhabit/day $=\mathrm{C}(\mathrm{mg}) \times 1,000 / \mathrm{DDD} \times$ inhab $\times \mathrm{T}$

Where:

C: total consume of the substance per year;

inhab: total inhabitants of the city according to official data (in Portuguese: Instituto Brasileiro de Geografia e Estatística-IBGE);

T: time period, that is, equivalent to 365 days of the year.

DDD: defined dose daily, which was recommended by RDC 58 of September 5, 2007.

This work was approved by the Ethics Committee in Research Involving Human Subjects of the UNINTER Educational Group under registration number 265 and CAAE 0001.0.074.370-09, according to the Resolution number 196, October 10, 1996 from the Brazilian National Health Council.

\section{RESULTS AND DISCUSSION}

A total of 1,641 balances sheets analyzed in the period from 2005 to 2008, 441 in the years 2005 and 2006, and 486 and 273 in the years 2007 and 2008. Of the psychotropic anorectic drugs scheduled in the B2 list prepared from Ordinance number 344/98 SVS/MS (Brasil 1998), only amfepramone, mazindol and fenproporex are dispensed in drugstores as well as in magistral pharmacies.

The dispensing of psychotropic anorectic drugs in capsules in drugstores in Belém, we observed that the three doses of amfepramone available on the market, the $75-\mathrm{mg}$ dose was the most dispensed in the four years studied. When analyzing the total dispensing of amfepramone in the years 2006 and 2007 , we observed a decrease in the dispensing of this drug in 2008. The dispensing of Fenproporex in capsules in the same period increased, while in 2008 there was also a drastic reduction in its sales. The dispensing of mazindol in capsules 
showed an increase in 2006 and in the following years a decrease (2007 and 2008).

Table 1 shows the total dispensing of anorectic drugs in grams in magistral pharmacies and drugstores. Amfepramone was the anorectic most dispensed, followed by fenproporex and mazindol in all years studied $\left(\mathrm{X}^{2}=238037925, \mathrm{p}<\right.$ $0.0001 ; 131300.01, \mathrm{p}<0.0001 ; 158408374, \mathrm{p}<0.0001$; 40488754, p < 0.0001; respectively). In 2006, amfepramone showed a decrease followed by an increase in 2007, but the results were not statistically significant. However, in 2008 a significant reduction in the total proportion of grams consumed was observed $\left(\mathrm{X}^{2}=23.19, \mathrm{p}<0.001\right)$. A similar behavior was observed in relation to fenproporex $\left(X^{2}=15.03\right.$, $\mathrm{p}<0.01)$ and mazindol $\left(\mathrm{X}^{2}=9.45, \mathrm{p}<0.001\right)$.

The results also show that the highest dispensing of anorectics occurred in magistral pharmacies compared to drugstores, for all anorectics studied over the years ( $\mathrm{p}<$ 0.0001 ). Figure 1 shows the differences between anorectic consumption and the decrease through the years (20052008), mainly after the issue of resolution RDC 58/2007 (Brasil 2007).

Table 2 shows the DDD of each substance in grams per year. In 2005, amfepramone was the drug most dispensed in drugstores (DDD 109) as well as pharmacies (DDD 2166). This profile persisted in 2006 and 2007. In 2008, the dispensing of these drugs was reduced in both drugstores and pharmacies, but this anorectic was still the most dispensed in Belém. Also, the results showed that the second appetite inhibitor most sold was fenproporex when compared to mazindol $\left(\mathrm{X}^{2}=10539.266, \mathrm{p}<0.0001\right)$.

Carneiro (2008) has demonstrated that in Belo Horizonte, in the year of 2003, the consumption of anorectics was superior to fenproporex than other drugs. These results are different from the data reported in this work, where in all years studied amfepramone had a more elevated DDD in both pharmacies and drugstores. Although Belém has five times more drugstores registered in the Health Surveillance when compared to the number of magistral pharmacies, the greatest amount of dispensing of anorectics occurred in magistral pharmacies.

Taking into account that these drugs are prescribed for the treatment of obesity, factors such as sedentary lifestyle and fast-food diet may have contributed to the obese population and may also have increased in prevalence, and so the increase in consumption of anorectics is justified (Nappo and Carlini 1994; Nappo et al. 1998; Nappo 2002).

Table 1 - Dispensing of anorectic drugs in grams in the drugstores and magistral pharmacies in Belem/Brazilian Amazon region.

\begin{tabular}{|c|c|c|c|c|c|c|c|c|c|c|c|c|}
\hline \multirow{3}{*}{ Drug } & \multicolumn{12}{|c|}{ DRUGSTORES } \\
\hline & \multicolumn{3}{|c|}{2005} & \multicolumn{3}{|c|}{2006} & \multicolumn{3}{|c|}{2007} & \multicolumn{3}{|c|}{2008} \\
\hline & $\mathrm{av}^{*}(\mathrm{~g})$ & $\%$ year & $\begin{array}{c}\% \text { all } \\
\text { years }\end{array}$ & av $(g)$ & $\%$ year & $\begin{array}{c}\% \text { all } \\
\text { years }\end{array}$ & av (g) & $\%$ year & $\begin{array}{c}\% \text { all } \\
\text { years }\end{array}$ & av $(g)$ & $\%$ year & $\begin{array}{c}\% \text { all } \\
\text { years }\end{array}$ \\
\hline Amfepramone & $6,689 \cdot 500^{\# \dagger}$ & 88.06 & 30.84 & $6,530.000^{\# \dagger}$ & 86.99 & 30.11 & $6,925.000^{\# \dagger}$ & 86.54 & 31.93 & $1,539.500^{\dagger}$ & 84.63 & 7.09 \\
\hline Fenproporex & $873.750^{\#}$ & 11.50 & 27.87 & $938.500^{\#}$ & 12.50 & 29.93 & $1,050.500^{\#}$ & 13.13 & 33.50 & $272.250^{\#}$ & 14.97 & 8.68 \\
\hline Mazindol & $33.580^{\#}$ & 0.44 & 31.66 & $38.400^{\#}$ & 0.51 & 36.20 & $26.820^{\#}$ & 0.34 & 25.28 & $7.260^{\#}$ & 0.40 & 6.84 \\
\hline \multirow[t]{2}{*}{ TOTAL } & $7,596.830$ & 100.00 & & $7,506.900$ & 100.00 & & $8,002.320$ & 100.00 & & $1,819.010$ & 100.00 & \\
\hline & \multicolumn{12}{|c|}{ MAGISTRAL PHARMACIES } \\
\hline Amfepramone & $132,095.289^{\# \dagger}$ & 92.84 & 41.98 & $71,555.940^{\# \dagger}$ & 92.13 & 22.74 & $86,989.024^{\# \dagger}$ & 92.26 & 27.65 & $23,961.215^{\dagger}$ & 89.36 & 7.61 \\
\hline Fenproporex & $10,084.488^{\#}$ & 7.09 & 38.55 & $6,041.161^{\#}$ & 7.78 & 23.09 & $7,225.703^{\#}$ & 7.66 & 27.62 & $2,805.075^{\#}$ & 10.46 & 10.72 \\
\hline Mazindol & $108.904^{\#}$ & 0.08 & 36.57 & $71.644^{\#}$ & 0.09 & 24.05 & $68.445^{\#}$ & 0.07 & 22.98 & $48.799^{\#}$ & 0.18 & 16.38 \\
\hline \multirow[t]{2}{*}{ TOTAL } & $142,288.681$ & 100.00 & & $77,668.745$ & 100.00 & & $94,283.172$ & 100.00 & & $26,815.089$ & 100.00 & \\
\hline & \multicolumn{12}{|c|}{ Total ( DRUGSTORE AND MAGISTRAL PHARMACIES) } \\
\hline Amfepramone & $138.784 .789^{\# \dagger}$ & 92.59 & 41.98 & $71,555.940^{\# \dagger}$ & 91.67 & 22.74 & $86,989.024^{\# \dagger}$ & 91.81 & 27,65 & $23,961.215^{\dagger}$ & 89.05 & 7.61 \\
\hline Fenproporex & $10.958 .238^{\#}$ & 7.31 & 38.55 & $6,041.161^{\#}$ & 8.19 & 23.09 & $7,225.703^{\#}$ & 8.09 & 27,62 & $2,805.075^{\#}$ & 10.74 & 10.72 \\
\hline Mazindol & $142.484^{\#}$ & 0.09 & 36.57 & $71.644^{\#}$ & 0.12 & 24.05 & $68.445^{\#}$ & 0.09 & 22,98 & $48.799^{\#}$ & 0.19 & 16.38 \\
\hline TOTAL & $142,288.681$ & 100.00 & & $77,668.745$ & 100.00 & & $94,283.172$ & 100.00 & & $26,815.089$ & 100.00 & \\
\hline
\end{tabular}

*(av) absolute values; ** (\%) percentage that represents each substance over the years. [av(year)x100/av(total)]; \# indicates comparisons between 2005,2006 and 2007 to 2008 (chi-square test, $p<0.001$ ); $†$ indicates comparisons between the substances fenproporex and mazindol (chi-square test, $p<0.001$ ). 

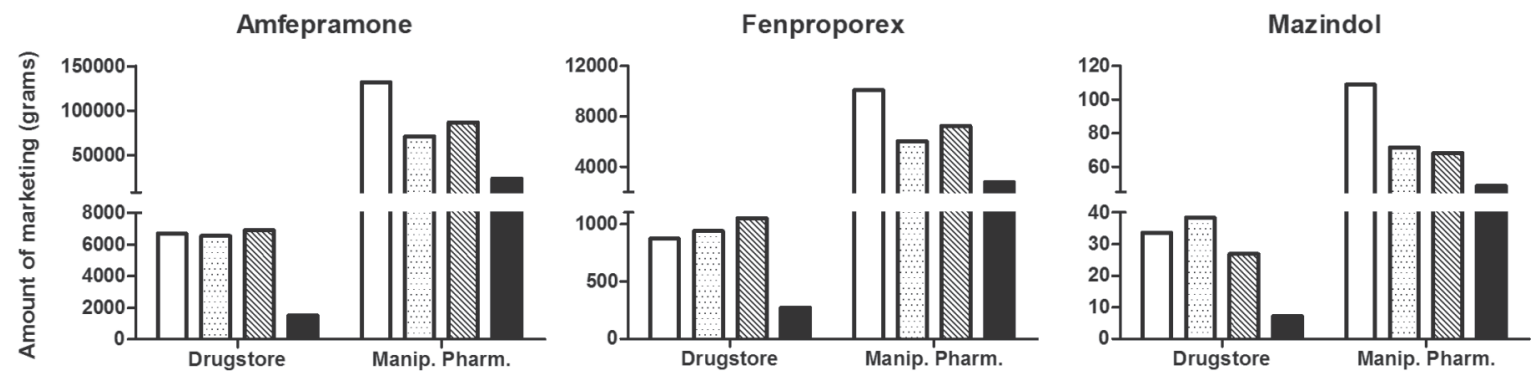

$\square 2005$

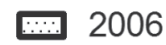

2008

Figure 1 - Dispensing of anorectic drugs in grams in the drugstores and manipulation pharmacies in Belém/Brazilian Amazon region, from 2005 to 2008.

The Federal Medicine Council, through Resolution number 1477/97 (Brasil 1997), recommends that treatments for obesity restrict prescriptions of anorectics to strictly recommended cases, following specific technical-scientific criteria, where the exaggerated use of medication to lose weight becomes unjustifiable (Behar 2002).

Recently, resolution RDC number 58 of September 5, 2007, issued by the National Health Surveillance Agency (ANVISA), aimed to improve the control and supervision of medicinal substances subject to special control, including anorectics. This legislation came into force in Belém in 2008, leading to an intense dissemination by local DEVISA in all communication media (television, newspaper and radio) aiming to inform the public (prescribers, dispensers and users) (Mancini 2008), in addition to forwarding official documents to the pharmaceutical establishments to reinforce the implementation of that resolution.

The advent of RDC 58/2007, which was more stringent, may corroborate the results obtained in this study, because it was found that in 2008 there was quite a significant drop in the dispensing of anorectics studied at both establishments, magistral pharmacies and drugstores. A report published by

Table 2 - DDD of anoretics substances in the drugstores and magistral pharmacies from Belém/Brazilian Amazon region.

\begin{tabular}{|c|c|c|c|c|}
\hline \multicolumn{5}{|c|}{ DRUGSTORES AND PHARMACIES } \\
\hline \multirow{2}{*}{ Drug } & 2005 & 2006 & 2007 & 2008 \\
\hline & $\mathrm{DDD}^{*}$ & $\mathrm{DDD}^{*}$ & $\mathrm{DDD}^{*}$ & $\mathrm{DDD}^{*}$ \\
\hline Amfepramone & $2276^{\# \dagger}$ & $1280^{\#+}$ & $1540^{\#+}$ & $418^{\dagger}$ \\
\hline Fenproporex & $431^{\#}$ & $274^{\#}$ & $325^{\#}$ & 121 \\
\hline Mazindol & $93^{\#}$ & $72^{\#}$ & $62^{\#}$ & 36 \\
\hline
\end{tabular}

*(DDD) defined dose daily; \# indicates comparisons between 2005, 2006 and 2007 to 2008 (chi-square test, $p<0.001$ ); $†$ indicates comparisons among the substances fenproporex and mazindol (chi-square test, $p<0.001$ ). the International Narcotics Control Board (2005) affirmed that some regulatory intervention can reduce indiscriminate use of anorectics and noted that Chile and Argentina reduced the dispensing of anorectics by $90 \%$ through control measures, supporting the results of this work.

According to the 2005 Report of the International Narcotics Control Board (International Narcotics Control Board 2005), the per capita consumption of anorectics has increased in Brazil, Australia, Czech Republic and Singapore. In the period from 2002 to 2004, Brazil, United States of America, Korea and Singapore, in that order, had the highest per capita consumption of these drugs (JIFE 2007), and thus, the Brazil government needed to reduce the indiscriminate use of the appetite suppressant.

Recently, the ANVISA intended to prohibit the prescription of anorectics in Brazil, affirming that the risks are higher than the benefits for the public. This discussion was not finalized, and according to ANVISA, this issue will be further debated in the future (ANVISA 2011a; 2011b).

Pharmacoepidemiological studies are indispensable for the detection of deviation in drug utilization, which makes people susceptible to health risks, providing a robust tool to support decision making and, if necessary, intervention from the health surveillance monitoring system to control and minimize risks to public health.

\section{CONCLUSIONS}

This work showed that the dispensing of anorectic drugs decreased in the year 2008 as a result of the implementation of RDC 58/07, and that the magistral pharmacies were responsible for more dispensing of psychotropic substances when compared to drugstores. Also, the anorectic drug most dispensed in the city of Belém in the period from 2005 to 2008 was amfepramone, and RDC number 58 of September 5 , 2007 was a mark in the policy of reducing the sale of anorectic drugs in drugstores and magistral pharmacies in Belém. 


\section{ACKNOWLEDGEMENT}

To the Department of Health Surveillance for permission to carry out this research.

\section{REFERENCES}

Allison, D.B.; Fontaine, K.R.; Heshkas, S.; Mentore, J.R.; Heymsfield, S.B. 2001. Alternative treatments for weight loss: a critical review. Critical Reviews in Food Science and Nutrition, 41: $1-28$

Arrais, P.S.D.; Coelho, H.L.L.; Batista, M.C.D.S.; Carvalho, M.L.; Righi, R.E.; Arnau, J.M. 1997. Perfil da automedicação no Brasil. Revista de Saúde Pública, 31: 71-77.

Associação Brasileira para o Estudo da Obesidade e da Síndrome Metabólica (ABESO) 2009. Diretrizes Brasileiras de Obesidade, 3: 1-83. (http://www.abeso.org.br/pdf/diretrizes_brasileiras_ obesidade_2009_2010_1.pdf). Accessed on February 19, 2011.

Behar, R. 2002. Anorexígenos: indicaciones e interacciones. Revista Chilena de Neuro-psiquiatría, 40: 21-36.

Brasil. Conselho Federal de Medicina. Portaria 1477 de 11 de julho de 1997.

Brasil. Agência Nacional de Vigilância Sanitária (ANVISA) 2011a. Nota Técnica: Avaliação de eficácia e segurança dos medicamentos inibidores de apetite, 1-89. (portal.anvisa.gov. $\mathrm{br} / \mathrm{wps} / \mathrm{wcm} /$ connect/c53fdd0045d07478be65bfe99fa014e7/ Avalia\%C3\%A7\%C3\%A3o+de+efic\%C3\%A1cia+e+seguran $\% \mathrm{C} 3 \% \mathrm{~A} 7 \mathrm{a}+\mathrm{dos}+$ medicamentos+inibidores+do+apetite+Final. pdf?MOD=AJPERES). Accessed on April 14, 2011.

Brasil. Agência Nacional de Vigilância Sanitária (ANVISA) 2011 b. Audiência dos anorexígenos mobiliza profissionais de saúde. (portal.anvisa.gov.br/wps/portal/anvisa/home/!ut/p/c4/04_ 8K8xLLM9MSSzPy8xBz9CP0os3hnd0cPE3MfAwMDM ydnA093Uz8z00B_AwN_Q_2CbEdFAL9EuZ0!/?WCM_ PORTLET=PC_7_CGAH47L0006BC0IG5N65QO0875_ WCM\&WCM_GLOBAL_CONTEXT=/wps/wcm/connect/ anvisa/anvisa/sala+de+imprensa/noticias/audiencia+dos+anore xigenos+mobiliza+profissionais+de+saude). Accessed on April 4, 2011.

Brasil. Agência Nacional de Vigilância Sanitária (ANVISA). Portaria $\mathrm{n}^{\circ} .344$, de 12 de maio de 1998. Aprova o Regulamento Técnico sobre substâncias e medicamentos sujeitos a controle especial.

Brasil. Agência Nacional de Vigilância Sanitária (ANVISA). Resolução no ${ }^{\circ}$. 58, de 05 de setembro de 2007. Dispóe sobre o aperfeiçoamento do controle e fiscalizaçáo de substâncias psicotrópicas anorexígenas e dá outras providências.

Campbell, I. 2003. The obesity epidemic: can we turn the tide? Heart, 89: 2-24.

Carneiro, M.F.G.; Guerra Junior, A.A.; Acurcio, F.A. 2008. Prescrição, dispensação e regulação do consumo de psicotrópicos anorexígenos em Belo Horizonte, Minas Gerais, Brasil. Cadernos de Saúde Pública, 24(8): 1763-72.

International Narcotics Control Board (INCB) 2005. Report of the International Narcotics Control Board for 2004, 1-99. (www. incb.org/pdf/e/ar/2004/incb_report_2004_full.pdf). Accessed on April 4, 2011.
Jeffreys, M.; McCarron P.; Gunnell, D.; McEwen J.; Smith, G.D. 2003. Body mass index in early and mid-adulthood, and subsequent mortality: a historical cohort study. International Journal of Obesity and Related Metabolic Disorders, 27: 13911397.

Junta Internacional de Fiscalização de Entorpecentes (JIFE), 2007. Relatório Anual 2007. Press release No 8, 1-9. (http://www. unodc.org/pdf/brazil/JIFE/OBrasilnoRelatorioJIFE.pdf). Accessed on April 4, 2011.

Mancini, M. Remédio para emagrecer. Entrevista concedida a Dráuzio Varella. (http://www.drauziovarella.com.br/ ExibirConteudo/2733/remedios-para-emagrecer/pagina1/acaodos-medicamentos). Accessed on April 4, 2011.

Nappo, S. A. 2002. Use of anoretic amphetamine-like drugs by brazilian woman. Eating Behaviors, 153-165.

Nappo, S.A.; Carlini, E.A. 1994. Anoréticos: situação atual no Brasil. Arquivos Brasileiros de Endocrinologia \& Metabologia, 38: 69-75.

Nappo, S.A.; Oliveira, E.M.; Morosini, S. 1998. Inappropriate prescribing of compound antiobesity formulas in Brazil. Pharmacoepidemiology Drug Safety, 7: 207-212.

Noto, A.R.; Carlini, E.A.; Mastroianni, P.C.; Alves, V.C.; Galduróz, J.C.F.; Kuroiwac, W.; Csizmar J.; Costa, A.; Faria, M.A.; Hidalgo, S.R.; Assis, D.; Nappo, S.A. 2002. Analysis of prescription and dispensation of psychotropic medications in two cities in the State of São Paulo, Brazil. Revista Brasileira de Psiquiatria, 24: 68-73.

Perini, E.; Acurcio, F.A. Farmacoepidemiologia. 2000. Ciências farmacêuticas: uma abordagem em farmácia hospitalar, p. 85-108. In: Gomes, M.J.V.M.; Reis, A.M.M., organizadores. Editora Atheneu, Belo Horizonte, Minas Gerais.

Philipson, T. 2001. The world-wide growth in obesity: an economic research agenda. Health Economics, 10: 1-7.

Salzano, F.T.; Cordás, T.A. 2004. Tratamento farmacológico de transtornos alimentares. Revista de Psiquiatria Clínica, 31: 188-194.

Sartorelli, D.S.; Granco, L.J. 2003. Tendências do Diabetes Mellitus no Brasil: o papel da transição nutricional. Cadernos de Saúde Pública, 19: S29-S36.

Wadden, T.A.; Berkowitz, R.I.; Womble, L.G.; Sarwer, D.B.; Phelan, S.; Cato, R.K.; Hesson, L.A.; Osey, S.Y.; Kaplan, R.; Stunkard, A.J. 2005. Randomized Trial of Lifestyle Modification and Pharmacotherapy for Obesity. The New England journal of medicine, 353: 2111-2120.

Wannmacher, L. 2004. Obesidade: evidências e fantasias. Uso Racional de Medicamentos: temas selecionados, Organizaçáo Mundial de Saúde - Brasil, Brasília, 1: 1-5.

World Health Organization (WHO) 1997. World health report 1997. (www.who.int/whr/1997/en/index.html). Accessed on April 4, 2011.

World Health Organization (WHO) Collaborating Centre for Drug Statistics Methodology. Anatomical therapeutic chemical (ATC) index with defined daily doses (DDDs). (www.whocc. no/use_of_atc_ddd). Accessed on February 2, 2011.

Recebido em 04/02/20111

Aceito em 01/09/2011 